\section{Zuzana Čížiková}

Univerzita v Belehrade

Filologická fakulta

Katedra slavistiky

z.cizikova@fil.bg.ac.rs
УДК 821.162.4.09

https://doi.org/10.18485/slavistika.2021.25.1.19

Оригинални научни рад примљено 20.05.2021.

прихваћено за штампу 17.06.2021.

\title{
POSTAVA V PRÓZE MÁRIE KOTVÁŠOVEJ-JONÁŠOVEJ
}

Literárnu postavu v próze pre deti a mládež slovenskej vojvodinskej autorky Márie KotvášovejJonášovej vnímame predovšetkým cez niekol'ko dôležitých problémových okruhov ako sú detský aspekt, otázka mimetizácie a referenčného odkazu na mimotextovú realitu, respektíve cez vzt’ah autenticity a štylizovanosti v umeleckom texte. Kategóriu postavy si všímame aj vo vzt’ahu k detskému čitatel'ovi, v zmysle detského stotožnenia sa s literárnymi vzormi, ktoré mu pomáhajú v kognitívnom a duševnom procese dozrievania. Na kreovanie detskej postavy majú dosah i zvolené rozprávačské postupy a stratégie či žánrové súvislosti.

Kl'účové slová: Mária Kotvášová-Jonášová, literárna postava, detský aspekt, autentickost', štylizovanost', detský čitatel'.

Literary characters in fiction for children and youth written by Mária Kotvášová-Jonášová, a Vojvodinian-Slovak author, are primarily observed through several important aspects. These aspects are that of a child, the issue of mimesis and the reference to reality outside the text, observing the relation of authenticity and stylization in a literary text. The category of the character is also perceived through their relation towards a child reader, in the sense of a child's identification with literary models helping the child to mature both cognitively and spiritually. The chosen manners and strategies of storytelling, as well as generic contexts, also influence the creation of a child character.

Keywords: Mária Kotvášová-Jonášová, literary character, aspect of a child, authenticity, stylization, a child reader

Literárna postava ${ }^{1}$ je popri kategórii rozprávača kl'účová v štruktúrovaní a aj ontológii epického textu, resp. narácie. Kým rozprávač viacej prislúcha naratívnej rovine, postava je tesnejšie zviazaná s rovinou príbehu. Literárnu postavu môžeme definovat' ako osobu, ktorá vystupuje v literárnom diele a je nositel'om nejakej udalosti, čo má korene ešte vo formalizme a štrukturalizme (Kubíček a kol. 2013: 41). Ak niet deja bez jeho nositel'a - postavy, platí aj opačne, postava či subjekt si vyžaduje nejakú akciu. V poetike a predovšetkým v naratológii sa vykryštalizovali dve protichodné návrhy na uchopenie a analýzu kategórie literárnej postavy. Prvý sa odvíja od chápania textu ako napodobneniny skutočného sveta a o postavách sa hovorí na základe posudzovania podl'a správania a konania skutočných osôb. Na druhom póle tohto, zjednodušene povedané, mimetického chápania postavy je semiotický či štrukturalistický prístup, kde je postava znak, resp. konštrukt a kde postava neodkazuje k niečomu mimo textu, ale je funkčnou súčast'ou rozprávaného sveta (tamže: 59). Ako to už býva, extrémnost' anuluje otvorenost' a ústretovost' voči inakším názorom; aj ohl'a-

\footnotetext{
${ }^{1}$ Namiesto termínu literárna postava sa v závislosti od teoretickej koncepcie použivajú aj d’alšie ako sú subjekt, figúra, entita, resp. fikčná jednotlivina v teórii fikčných svetov L. Doležela. D. Hodrová napríklad hovorí o postavách definíciách a postavách hypotézach. Detailnejší prehl'ad k vývinu a výskumu kategórie literárnej postavy pozri vo Fořt 2008.
} 
dom tejto problematiky sa javí stredná cesta, na čo upozorňuje napr. teória literárnej komunikácie a kognitívna naratológia. Postavy sa v rétoricky zameranej naratológii vnímajú ako estetické kategórie, určené na angažovanie čitatel'a k určitému postoju, ako textom riadená recepcia (tamže: 62). Ale i vtedy si treba uvedomit', že vnímanie a následné interpretovanie postavy závisí od konkrétneho literárneho textu, raz literárny text viacej inklinuje $\mathrm{k}$ empirickému zažitiu, inokedy je viacej funkciou alebo znakom, ale nikdy nesmieme prekročit' ontologickú hranicu a postavu pokladat' za skutočného človeka. „Patrí teda do sveta rozprávania, z ktorého nemôže vystúpit' a konat' mimo konkrétnych súvislostí konkrétneho naratívneho sveta." (Harpán 1994: 210) A naopak, literárnu postavu nemôžeme nevzt'ahovat' ku aktuálnemu l'udskému svetu, aj vtedy ked' z jej reprezentatívnej funkcie nič nezostáva. Literárna postava stále bude patrit' iba do fikčného sveta, je literárne/textovo sprostredkovaná a preto nikdy nemôže byt' skutočná, ale ,[z]ůstáva v postavě tedy určité jádro reprezentativnosti, typovosti odvozované od naši zkušenosti s lidskou existencí v aktuálním světe" (Bílek 2003: 161). Ako epická kategória, úzko a neoddelitel'ne je spojená s ostatnými kategóriami ako sú rozprávač, udalosti a dej, čas a priestor.

Pre nás, vzhl'adom na predmet skúmania a tým je próza pre deti a mládež súčasnej slovenskej spisovatel'ky Márie Kotvášovej-Jonášovej (1957), je produktívne vnímanie literárnej postavy z tematického, mimetického a reprezentačného vzt’ahu k mimoliterárnej skutočnosti, predovšetkým z aspektu detského príjemcu. Aj ked' je každá postava vytvorená jazykom - predstavu o postave si čitatel’ vytvára na základe rozprávačovej (priamej a nepriamej) charakterizácie a prehovoru postáv (dialógu, monológu, priamej a nepriamej reči) a jej konania, pričom najčastejším modelom pri stvárňovaní literárnej postavy je človek (Harpáň 1994: 210). ${ }^{2}$ Na rozdiel od diskurzívneho (skúseného, poučeného, dospelého) príjemcu, ktorý si uvedomuje textom riadenú recepciu postavy (teda to, ako je modelovaná) diet’a postavu vníma ovel'a bližšie a bezprostrednejšie - inklinuje k naivnému čitatel'ovi. K tomu diet’a menej racionalizuje recepciu diela, viacej sa „Vžíva“ a prežíva to, čo sa stáva detskému hrdinovi. ${ }^{3}$ Detská postava nie je len kl'účovým prvkom v sujetovej výstavbe textu, ale má významné miesto $\mathrm{v}$ realizácii základných funkcií intencionálne zameranej tvorby pre deti (predovšetkým tej primárnej estetickej funkcie, ale i výchovnej, poznávacej, etickej, zábavnej). Práve prostredníctvom literárneho hrdinu sa môže realizovat' silná identifikačná väzba detského čitatel'a s detským hrdinom. ${ }^{4}$ Ked' sa literárny

${ }^{2}$ Je až banálne pripomenút', že postava môže byt' aj zviera, predmet, stroj či iná entita, ale s ohl'adom na poetické a intencionálne špecifikum literatúry pre deti aj toto si treba uvedomit'. Aj nami skúmaná autorka má ojedinelé prózy inklinujúce k žánru autorskej rozprávky, kde sa vyskytujú animálne a predmetové postavy.

${ }^{3} \mathrm{~V}$ našom príspevku budeme termíny literárna postava, literárny hrdina a občas i detský protagonista používat' v rovnakom význame a striedavo predovšetkým zo štylistických dôvodov. Aj ked' existuje tendencia termín hrdina používat' v zmysle jeho kladných charakteristík, napr. v opozícii $\mathrm{s}$ antihrdinom, kým termín literárna postava je v tomto zmysle neutrálnejšia. Spravidla sa v štúdiách o literatúre pre deti používa termín detský hrdina a detský protagonista.

${ }^{4}$ Od sedemdesiatych rokov sa v českej literárnej vede, najviac pričinením O. Chaloupku a V. Neskusila presadilo (z genologického hl'adiska) nadbytočné terminologické pomenovanie „príbehová próza zo života detí s referenčným hrdinom“, ktorý mal mat’ predovšetkým formujúcu funkciu na adresáta. 
teoretik a pedagóg Radoslav Rusňák zamýšl'a nad otázkou: Kto je literárny hrdina? prichádza k poznaniu, že ide o dôležitú komponentu detského duševného dozrievania ,lebo všetko, čo (diet’a - poz. Z. Č.) robí, je svojím spôsobom integrované a takto sa diet'a podiel'a na tvorení vlastnej osobnosti“ (Rusňák 2017: 55). Aj ked' je jasné, že ani celkom malé diet'a postavu nevníma vyslovene ako živú bytost' z aktuálneho sveta (v duchu svojich skúseností napr. aj s folklórnymi žánrami), ale psychologicky a mentálne je menej schopné príbeh racionalizovat' a viacej ho percipuje emočne a intuitívne, t. j. zážitkovo. V príbehovej próze sa diet’a cez postavu ako konajúceho subjektu vovádza do rozprávaného sveta a postava mu umožňuje, aby ten fiktívny svet posudzoval a hodnotil v rámci svojich psychických, mentálnych a poznávacích možností. Detský čitatel' si postavu dotvára podl'a svojho psychického ustrojenia, ktoré sa v detskom veku výrazne a dynamicky mení, ako zdôrazňuje aj Peter Zajac: „Literárny text prijíma diet’a spočiatku zástupne za skutočnost'; postupne vníma literárny text zástupne za literatúru, neskôr za literárny druh a žáner a až nakoniec si uvedomuje celú diferencovanú hierarchiu od literárneho textu cez literárny žáner a druh k autorskej a textovej jedinečnosti" (Zajac 1993: 81).

Spisovatel'ka Kotvášová-Jonášová sa vyprofilovala predovšetkým v žánrovom okruhu príbehovej prózy, resp. spoločenskej prózy pre deti a mládež. Základnou látkou jej umeleckého sveta tvorí žitý svet detí predškolského a školského veku. Transpozícia látky (skutočné udalosti a zážitky alebo „objektovú skutočnost’ ako materiálový podklad, zásobáreň témy“; Rakús 1999: 17) na tému a problém, teda na poetologickú kategóriu umeleckého diela sa koná pod silným vplyvom detského aspektu, s poznaním vývinových etáp detstva a s rešpektovaním recepčných možností detského čitatel'a. Tvorivá metóda tzv. reálnej fikcie, ked' ,je literárne dielo vytvorené napodobňovaním (mimetizáciou) reálneho života“ (Stanislavová 1996: 11) prispieva k možnosti príbeh detských hrdinov vnímat' ako súčast'/výsek zo skutočného sveta. V reálnej fikcii je postava stvárňovaná ako možný jednotlivec, jej konanie čitatel' posudzuje na základe svojich vlastných skúseností a hodnôt. Príbehy pre vekovo mladších čitatel'ov, respektíve dlhšie a kompozične zložitejšie prózy pre starších čitatel'ov autorka buduje na nosných konfliktných situáciách, ktoré v tenzívno-detenzívnom oblúku a dynamickom spáde rezultujú prekvapivou pointou. Rozpoznatel'ným znakom jej naratívneho sveta sú práve detské postavy spravidla ako aktéri stvárnených udalostí. Svojrázna ,životnost“ a ,vierohodnost'“ jej detských postáv je úzko spätá s príbehom. V krátkych žánrových formách sú postavy nositelia dynamického deja, kým na širšej ploche románu pre dospievajúcich ide o postavy charakterovo individualizované, ale sčasti i typovo modelované, ako na to ukážeme nižšie. Cez tematizovanie určitého životného problému najčastejšie vo vzt'ahu diet’a-dospelý sa aj postava problematizuje v zmysle jej vierohodného stvárnenia. To nie sú kladní hrdinovia „šuštiaci papierom“, ale detské postavy v mnohom podobné s „reálnym“ nezbedným diet'at'om, čo predstavuje priestor identifikácie sa detského čitatel'a s detskou postavou.

Spôsob výstavby a funkciu postáv v Kotvášovej-Jonášovej próze si ilustrujeme na dvoch rozsiahlejších prozaických textoch, kritikou pomenovaných ako romány: Mat' pätnást' je také t’ažké alebo Striptíz (2007) a Višňový lekvár (2013), ktoré záberom, rozsahom a tematizovaným problémom dovol'ujú komplexnejšie kreovanie postáv. K nim priradíme aj dve poviedky „Danka“ a „Damjan“ z knihy Sú to vážne veci 
(2010), kde sa už v názve odkazuje na detského protagonistu, okolo ktorého sa príbeh odvíja. Úvodné kreovanie postavy je u tejto autorky často hlavným prostriedkom vstupu do rozprávania. Protagonistka Dora v románe o dospievaní Mat' pätnást’... je zároveň i rozprávačkou príbehu. Postava sa „rodí“ a „žije“ svojím rozprávaním. V narácii sa zjavuje na scéne svojím výpovedným aktom o sebe a zároveň iniciuje komunikáciu s čitatel'om: „V poslednom období som vel'mi, vel'mi nešt’astná osôbka. Najnešt'astnejšia na svete. Neviete si ani predstavit', ako vel'mi trpím. Tuším moje dospievanie nie je normálne.“ (Kotvášová-Jonášová 2007: 5). Pripomína to Stanzelovho rozprávača ,ja s telom“ (Stanzel 1988: 50), telesná zakotvenost' postavy v diele sa často (najčastejšie vnútorným monológom) pripomína popisom telesných pocitov a príznakov: „Všetko je také popletené. Také t’ažké. V žalúdku ma začalo hriat', pálit', vriet'. Kolená sa mi podlomili. V očiach sa zatmelo“ (tamže: 72). Aj úvodná sebacharakteristika ukazuje na introvertný typ postavy, tu charakterizovaný predovšetkým jazykovo-štylistickými prostriedkami. Najmä časti, kde hovorí o sebe sú hyperbolizované a nadnesené, vyjadrené expresívnou lexikou a syntaxou: „Je to príšera. Hotová katastrofa. Cítim sa hrozne. Už pár dní ma moria rozličné duševné nálady. Som zmätená, rozpoltená a strašne, strašne rozcitlivená. Stále plačem, rumádzgam. Ja som jedna usmrkaná potvorka“ (tamže: 5). Dorina výpoved” je v súlade s revoltujúcim gestom dospievajúcej hrdinky, ktorá sa ponosuje na „t’ažké“ obdobie vo svojom živote. Zohl'adnením vekového aspektu dospievajúcej dievčiny (jazykom, horizontom skúsenostného a vedomostného poznania, tažkým procesom nadobúdania osobnostnej integrity a následne i identity) sa autorka v sujetovom spracovaní dopracovala k autentickému obrazu dospievania. Podl'a Zuzany Stanislavovej „autentická literatúra pre deti a mládež je teda taká, ktorá prináša dobovým detským čitatel'om aktuálnu, presvedčivú správu o svete, kódovanú prostredníctvom dešifrovatel’nej poetiky.“ (Stanislavová 1999: 138) Nastolená otázka autentickosti a štylizovanosti, v duchu zistení P. Zajaca (1999) a Z. Stanislavovej (1999) nevnímame tu za protikladné javy a ani ako výlučné kritérium hodnotenia, hoci ono má v súvislosti s intencionálnou literatúrou pre deti a mládež špecifické postavenie. V tvorbe pre deti autor musí vziat' do úvahy detský vek a ontogenetické schopnosti svojho potenciálneho príjemcu, čo nevyhnutne vyžaduje určitú štylizáciu alebo inak povedané ,„pojem autenticita $\mathrm{v}$ jeho ontologickom rozmere vo vzt’ahu k detskému aspektu možno však vykladat' ako taký výber dospelostného poznania, empatického ponoru, cítenia a taký spôsob ich transformácie, ktorý je adekvátny poznávacím a pocitovým možnostiam a potrebám detského sveta na určitom stupni ontogenetického a psychofyzického vývinu.“ (Stanislavová 1999: 138) Stanislav Rakús hovorí o „produkčnej náročnosti“ (Rakús 1999: 20) literatúry pre mládež v zmysle naliehavosti utvorit’ esteticky a recepčne náročnú výpoved' a zároveň i prít’ažlivú a oslovujúcu pre mladého čitatel'a. Pred autorkou teda vyvstával celý rad textotvorných operácii na tvarovaní umeleckého textu, aby výsledok naplnil obidve, Rakúsom načrtnuté, požiadavky. Pri vol'be priameho rozprávania (dost' frekventovaného v dielach pre dospievajúcich) sa zameriava na takú výpoved', čo bude blízka pocitovému svetu dospievajúceho čitatel'a, mienime však, že ten priestor vyhradený pre arteficiálnost' a umeleckost' nevyužila naplno, predovšetkým pre dominantné prvoplánové podanie príbehu. Prostredníctvom protagonistky sa sústred'uje na symptomatický časový úsek jej života (posledný ročník základnej školy) a problémový výsek - prvá láska a prvý bozk, medzil'udské vzt’ahy medzi vrstovníkmi, dospievajúcimi a dospelými a problémy či odklony, ako 
sú krádež, nehoda s alkoholom, roztržka s priatel'kou a pod. Hrdinkin pocit nepochopenia $\mathrm{v}$ rodine sa projektuje do hl'adania náhradného sociálneho prestoru vrstovníkov, aby sa po ,iniciačnej“ životnej skúsenosti k nej navrátila. Aj napriek tejto relatívne stereotypnej látke (spracovanej v slovenskej literatúre pre mládež v dielach viacerých autoriek ako sú K. Jarunková, J. Šrámková, E. Gašparová, J. Blažková a i.) autorka dokázala postavu Dory modelovat' v smere výraznej individualizácie. Svojrázna subjektivizácia či individualizácia postavy, podmienená aj priamym rozprávaním, prispieva k bezprostrednejšiemu zážitkovému osvojeniu si zo strany percipienta. Presvedčivá je najmä tam, kde popisuje svoje myšlienky a pocity neistoty, roztržitosti, stiesnenosti, bezvýchodiskovosti, na začiatku príbehu aj malodušnosti: „Č́m som sa previnila? Čo je to so mnou? Akoby sa všetko zlo tohto sveta rútilo na mňa. Som odporná, hnusná. Nula. Vel'ká nula. Vôkol mňa začína vírit’ čierňava. Nič sa mi nedarí. V mojom živote sa strieda malér za malérom. Všetci mnou opovrhujú.“ (Kotvášová-Jonášová 2007: 34) Najvýraznejšie sa postava nepriamo charakterizuje vo vnútornom monológu: „Cítila som sa bezmocne, mizerne, nanič. Vo mne a vôkol mňa - sama prázdnota. Občas rozmýšl’am, že sú veci, ktoré môj rozum nezvláda. Mám pocit, že som celkom zlyhala. Celý život mi je príšerne trápny. A taký t’ažký. (---) Je život strata času? Je? Nie je? Tuším, so mnou sa niekto zahráva. Ako keby som bola marioneta na nitkách. (---) Bože, čo mi je? Bláznim?“ (tamže: 104) Proces individualizácie prebieha cez autocharakteristiku, konanie a vo vzt’ahu k iným postavám. Od reflektovania situácie v úvodnej kapitole (personalizácie vo vnútornom monológu) narácia smeruje k rozprávaniu rozličných epizodických udalostí, čo tiež vnímame ako vedomú autorskú stratégiu v smere ústretovosti recepčným schopnostiam predpokladaného čitatel'a. Pri Dore sa čitatel'ské konkretizácie v mnohom môžu opierat' o ich vlastné životné skúsenosti (správanie a konanie, citová labilnost', nadužívanie problémov a pod.). Na druhej strane pri tejto postave cítit' tendenciu približovania sa k postave typu - reprezentuje dospievajúceho tínedžera, čo je naznačené už titulom románu. Ako relatívne časté sujetové prvky v tomto type prózy evidujeme napríklad konflikt s rodičmi, snaha patrit’ do nejakej neformálnej sociálnej skupiny, skúsenost's alkoholom a pod., čo prispieva k typizácii respektíve reprezentatívnosti pubertiačky v kratšom krízovom období svojho dozrievania. Dora je typická v tom zápase o svoju individualitu a postupne sa proces sebapoznávania v smere nadobúdania integrity a osobnostnej identity, najmä osobným zápasom o stabilizáciu vnútorných protirečivých pocitov, dostáva do uspokojivého štádia. Takýto hrdina detského čitatel'a obohacuje nielen v smere jeho dozrievania, ale i smere poznávacom (pre fungovanie vlastnej psychiky a zmätenosti v zásadných otázkach, aj erotickej iniciácie). Dokonca môže byt' pre čitatel'a skutočnejší ako reálne osoby, lebo dostávajú dojem, že poznajú aj hrdinov vnútorný život, dovidia aj na skryté starosti a túžby, napr. tajná Dorina túžba po prvom bozku. ${ }^{5}$ Dora verbalizuje aj tie pocity a vnútorné stavy, ktoré dospievajúci často nevie pomenovat'; pritom preferuje priame a esteticky menej pôsobivé vyjadrenia, napr. pri stretnutí s chlapcom: „,Trochu mnou myklo, ale nebolo to neviem aké zvláštne. Len potom, cestou, ked' ma chytil za ruku, aby som sa mu v tme nestratila, čo bolo vel'mi romantické, roztriaslo ma na celom tele. Žalúdok, ba celé telo mi stuhlo a srdce sa rozbúrilo. Krátko nato som pocítila ná-

\footnotetext{
${ }^{5}$ Ako to podotýka E. M. Forster v knihe Aspekty románu (Forster 1971), že l’ud’om v románe môžeme porozumiet' lepšie než naším najbližším priatel'om.
} 
val tepla, malátnost' či závrat, vyrazilo mi dych, stratila som vládu nad svojím telom, zapotácala som sa, ani neviem ako, ale cítila som sa v jeho silnom objatí, cítila som jeho dych..." (Kotvášová-Jonášová 2007: 108) alebo po pokuse o samovraždu priatel'ky Eny: „Prežívala som pocit viny. Videla som, že sa vyžíva v myšlienke na smrt'. Mala som jej v tom zabránit'. Mala som volat' jej mame. Mohla som si mysliet', že ten jej problém nezmizne sám od seba.“ (tamže: 95) V sujetovom pláne prostredníctvom jednotlivých udalostí protagonistka nadobudne vlastnosti empatickej a slušnej dievčiny; pomôže sociálne znevýhodnenej spolužiačke, prejavuje pochopenie k nešt’astnej priatel'ke Ene, s rodičmi sa nakoniec udobrí. Tento typ postáv inklinuje k pozitívnemu hodnotovému pólu. Dávid Dziak hovorí, že „,prosociálny literárny vzor je postava, ktorá asertívnym spôsobom prekonáva problémy počas príbehu, pričom sa vyznačuje humánnost’ou, je priatel'ská a empatická voči ostatným postavám, pomáha druhým a stará sa o nich, delí sa a spolupracuje s ostatnými a má úctu k sebe, ale aj k druhým.“ (Dziak 2019: 55) Pri Dore je to postupný proces vyhraňovania sa, čitatel' k nej môže zaujat' aktívny postoj - akceptovat', prijat' a rešpektovat' ju aj s nedostatkami a morálnymi pokleskami, teda v človekovej mnohorozmernej podstate.

Pri výstavbe hlavnej postavy a rozprávačky Tomášky Tomášovej vo Višňovom lekvári autorka $\mathrm{v}$ úvodnom krátkom textovom predstavovaní skonštruuje túto postavu samotným prehovorom a tým najpodstatnejším vlastným menom a priezviskom. Čitatel' dostáva základné koordináty jej vnímania, percipovania a hodnotenia. Od tejto prvotnej textovej stratégie cez jazykovú manifestáciu sa potom postupne v slede epizodických príhod Tomáška stáva postavou reprezentujúcou jedenást'ročné, charakterovo dost' vyhranené dievča. Znakového charakteru je napríklad prvotné oslovenie čitatel'a (a to hned' $\mathrm{v}$ trojnásobnom opakovaní) a predstavenie sa menom a priezviskom: „Nazdar. Ahoj. Čao. Chcem sa vám predstavit'. Prečo? Neviem presne prečo, ale asi len tak. Volám sa Tomáška Tomášová." (Kotvášová-Jonášová 2013: 7). Oslovenie a apostrofovanie odkazuje von z textu (do jeho referenčného rámca, k čitatel’ovi) a dovnútra textu. (Zajac 1999: 26) K označujúcim údajom autorka pridá „ešte niekol'ko slov“ o tom, v ktorej je triede a koho má v rodine. Znakovej podstaty je aj jej reč a príliš explicitné poukázanie na jej charakterovú črtu a to je pochabost' a vtipnost' „Tonička - výmyselníčka“ (Kotvášová-Jonášová 2013: 7), od ktorej sa budú odvíjat viaceré príbehy. Tým, že ju autorka označí za blázonku a výmyselníčku dopredu ju ohodnotí a klasifikuje, čím naznačí, čo čitatel' od knihy môže očakávat'. Tento atribút výrazne ovplyvňuje d'alšiu recepciu textu a bude sa už iba nepatrne modifikovat'. Do konca knihy na úvodnú charakteristiku sa navrstvujú d’alšie, ale v podstate vel'mi podobné vlastnosti kulminujúce záverečnou prózou tematizujúcou krádež peňazí starým rodičom na vytúžený dotykový mobil. Takto „konštruovaná“ postava a rozprávačka môže potom „,vykročit“ do sveta svojich malých každodenných dobrodružstiev. Úvodná kapitolka má integrujúcu a kompozičnú funkciu - predstavovanie postavy a rozprávačky tvorí rámec jednotlivých poviedok spojených do knižného celku. ${ }^{6}$ Postava je tu akoby médium, cez ktoré sa bude sprostredkovat' všetko čo nasleduje (príbehy a udalosti, hodnotenie vedl'ajších postáv, rodinného a školského

${ }^{6}$ Domnievame sa, že autorka tento úvod a rozprávačku dodatočne skonštruovala, aby kompozične a sujetovo scelila jednotlivé krátke prózy do rozsiahlejšieho žánrového celku, v čom nás ubezpečuje aj skutočnost', že niektoré prózy boli predtým uverejnené časopisecky a meno rozprávačky sa tam neuvádza. 
prostredia). Čitatel'ovi sa ponúka možnost' identifikovat' sa a akceptovat' zvolený uhol pohladu. Tomáška, v zhode so svojím vekovým a skúsenostným limitom, viacej opisuje to, čo sa jej stáva(lo), ako čo dianie hodnotí: „,- Cvok, - cvokne kl’učka, dverce sa roztvoria a ja stojím zoči-voči dedkovi. Čo teraz, Čo teraz?! Bezmocne stojím. Kútikom oka si všímam vedro v dedkových rukách. Ked' ním ovalí, zabije ma! Ujdi! Hovorím si. Bež! Nohy kamene. To vedro sa zrazu zdvihne... a člap. Zaleje ma more vody." (tamže: 52). Autorka pritom občas porušuje optiku ja rozprávania; priamy rozprávač (Tomáška) o sebe vypovedá z pozície objektívneho rozprávača, predovšetkým v dialógoch: „,- Mama, tvoju Toničku bolí noha.“ (tamže: 11) alebo „,- A čo kúpite Maši?"“ (tamže: 13). Takéto scudzovanie sa hrdinky tu vnímame ako jazykovú hru, čo odkazuje na ranné vývinové fázy diet’at'a. Aj na iných miestach dostávame predstavu hrdinkinej (prehnanej?) infantilnosti, napr. v opise spolužiaka Andreja: „Zdalo sa mi, že sa nafukuje ako moriak. Ten strýkov. Strýko ma štyri morky a jedného moriaka. Morky sú trochu väčšie sliepky a moriak je ešte väčší a nafúka sa stále, ked' mu strýko zaspieva: Sopel' moriak, / nafúkaj sa / a ty Tonka / nehnevaj sa, / blu, blu, blulu. Na to strýkovo blu, blu, blu si tiež zabubluje - blu, blu, blu - a nafúka sa. Ako balón. Velikánsky. Andrejovi sa ani spievat' nemuselo a bol nafúkaný ako moriak. Strýkov.“ (tamže: 61). Prevaha príbehovej akčnosti nad psychologickou introspekciou (akú sme postrehli pri postave dospievajúcej Dory) ovplyvňuje aj podobu epického textu. Tomáška, aj ked' vystupuje ako jedna z postáv zdiel'aných príbehov, spravidla sa prezentuje ako ja rozprávajúce a nie aj ja prežívajúce, resp. reflektujúce svoje vnútro. Napríklad, v kapitole Narodeniny sa v sujetovej línii sústred'uje na prípravu narodeninovej oslavy a cez dramatický dialóg s matkou aj na temporálny moment čakania. Neúspešnú oslavu narodenín psychicky neprežíva: „Poberiem sa do izby. Z dverí sa hodím na postel'. Ved' som bola dobrá, správala som sa múdre. Celý deň. A nikto neprišiel. Zaspat'. Zabudnút'.“ (tamže: 30). Esteticky účinne pôsobí podanie prvých fyzických zmien u dievčat (prvé chĺpky v podpazuší, prvá menštruácia) autorskou stratégiu okl'uky a tajomstva. Využíva na to predovšetkým náznakovost', typografické zvýraznenie a jazykovú hru:

„- Ja som dospievajúce dievča, - vyhlásila som spolužiačkam, ked’ som vystrčila nos z kúpel'ne. Čakali predo dvermi. - A TO sa má aj vám stat'.

- Čo? - nechápali.

- TO, - vravím im. - TO, čo sa stalo mne, čo nevidiet' sa stane aj vám. Aj vy budete krvácat'.

- Tu? Teraz? Prečo?

- Jáj, či ste hlúpučké, pretože to tak v živote žien chodí, - tvárila som sa vel’mi učenlivo a vlastne som iba opakovala učitel'kine slová.

- Jáj, teraz viem, - vztýčila ukazovák nad hlavu Patrícia. - Ked’ som odchádzala, mama mi rozprávala, že sa mi niečo môže stat' na výlete. Vraj môžem dostat' memštru...či monštru...? Uf, ako sa to aj volá? - capla sa dlaňou po čele, len tak zadunelo. - Viem, je to monštrum.“ (tamže: 37) Čitatel'ská recepcia Višňového lekváru ukázala, že tematizácia a spracovanie týchto tabuizovaných tém má aj vzdelávaciu funkciu.

Iný typ výstavby postavy predstavujú postavy z rovnomenných próz „Danka“ a „Damjan“, ktoré v sebe okrem tematického horizontu majú aj silný didaktický rozmer. Postava Danky odkazuje na samol’úbu a bezočivú dievčinu, ktorá sa tak správa 
najmä voči vlastnej matke. Z rozprávačských postupov autorka siahla po objektívnom rozprávačovi a predovšetkým využíva dramatický dialóg medzi matkou a Dankou. Nadužívanie dialógu kompenzuje malú dramatickost' príbehu - matkin odvoz meškajúcej dcéry na dohodnuté stretnutie. Danka je charakterizovaná polemickým a drzým prehovorom, vybočujúcim z konvenčnej a očakávanej konverzácie dvoch blízkych, aj vzt'ahovo nerovnocenných osôb. Danka diriguje, rozkazuje, posmieva sa matke, ktorá je ústretová a vel'mi zhovievavá: „,- Dobre, mama, prestaň mi stále dohovárat'. Ideme, ideme, poskoč, ty môj šaško, poskoč, - pohŕdavo ju pobádala.

- Dana, Dana, - krútila mama hlavou.“ (---)

- Aká vtipná! Hodíš sa do cirkusu. Ozajstný šašo. Bazén nemá nohy! Ha, ha. Smejte sa l'udia! Bazén nemá nohy! Svetská hlúpost', radšej čuš! - skríkla.

Mama sa zarazila“ (Kotvášová-Jonášová 2010: 57).

Výchovná funkcia je zašifrovaná v netextovom priestore; čitatel' si ju dešifruje ako poučku o tom, ako sa netreba správat' $k$ svojim rodičom. Silný odkaz má predovšetkým poukázanie na elementárne veci akou je aj prejav vd’aky za pomoc svojim najbližším:

„-Z čoho si ju vysmiala?

- Z najhlúpejšej hlúpej hlúposti.

- Zavolaj jej! Povedz, že l'utuješ. Ospravedlň sa jej!

- Mame sa mám ospravedlnit?

- No.

- To je len mama! (tamže: 62).

Cez postavu Danky sa ukazuje ako sa niektoré samozrejmé veci stávajú elementárnymi a vo vzt’ahoch i esenciálnymi. Danka si na konci uvedomuje ako sa $\mathrm{k}$ mame správala, ale hranicu neprekročí. Postava Danky je príkladom na kreovanie detskej postavy jej prehovorom a bez priamej charakteristiky.

Jednou z významovo najzat aženejších postav je chlapčenský hrdina Damjan z rovnomennej poviedky pretože sa prostredníctvom nej tematizuje inakost' a hendikep, čo je v kontexte autorkinej tvorby ojedinelým príkladom. Deficitnost' Damjanovho sveta je podmienená jeho sociálnou situáciou, pochádza z neúplnej rodiny - žije s otcom, ktorý sa znovu ožení a prvotná Damjanova nádej, že „nová mama“ stabilizuje jeho život sa nenaplní (macocha ho psychicky a fyzicky týra). Príbeh je podaný striedaním personálneho rozprávača či rozprávača svedka a dialogických častí - rozhovoru Damjana so spolužiakmi a triednym učitel'om. Vedlajšie postavy sú stratifikované na pomocníkov (spolužiak Milan a triedny učitel') a záškodníkov (spolužiačka Mirka) a ich protikladné rozloženie zvýrazňuje ich sujetovú funkciu. V ich modelovaní autorka použila protiklad empatického, ústretového a bezohl'adného, egoistického prístupu k znevýhodnenej postave. Postava Damjana je predovšetkým objektom rozprávania; hlbšia psychologická sonda do jeho vnútorného sveta by postave pridala na presvedčivosti, ale mienime, že aj takto predstavená (z vonkajšej perspektívy) môže zapôsobit' na detského príjemcu. Postava so znevýhodnením môže detského čitatel'a viest' k etickým hodnotám (k pocitom ako sú empatia, súcit a solidarita s tým druhým).

Na vybraných textoch $\mathrm{z}$ tvorby Márie Kotvášovej-Jonášovej vidiet' preferované autorské stratégie $\mathrm{v}$ kreovaní detských postáv a čiastočne i v štylizácii literárne- 
ho textu, kde preferuje autenticitu reálnosti. Pri modelovaní postáv sa autentickost' prejavuje cez zohl'adnenie detského aspektu ako klúčového princípu tvorby pre deti a mládež. Pri postave tínedžerky Dory aj napriek určitej typizácii inklinuje k jej individuálnemu tvarovaniu; epické dianie sa hodnotí z jej vnútornej perspektívy a v popredí je introspekcia. Rešpektujúc vekové limity druhej skúmanej postavy Tomášky autorka ju intenčne, už pred vstupom do epického diania charakterovo modeluje a potom jej profil iba dotvára. Priame rozprávanie by sa tu bez vel'kých zásahov mohlo nahradit' personálnym, resp. autorským rozprávaním, čo ukazuje predovšetkým na jej rozprávačskú funkciu. Obidve postavy sú zaujímavé uplatnením detského aspektu, respektíve riešením otázky autentickosti a štylizovanosti, čo nevyhnutne v tvorbe pre deti súvisí aj s modelovaním detských postáv. Tým, že spisovatel'ka tematizuje opakujúce sa premeny a fázy životného cyklu (detstva, puberty) kreovanie postáv je poplatné určitým univerzálnym zákonitostiam danej vývinovej fázy, čo vedie k typizácii postáv. Ako sme naznačili, typizácia však v konkrétnych vnútrotextových reláciách nevylučuje individualistický obraz postavy (jazyk, detský pohl'ad, detské infantilné reagovanie a pod.). Aj ked' autorka v celom svojom prozaickom opuse preferuje priame rozprávanie s ilúziou bezprostrednosti, v próze „Danka“ je hrdinka charakterizovaná len nepriamo - svojim prehovorom a konaním. V próze „Damjan” striedaním viacerých perspektív a formou dialógu sa detský čitatel' s postavou dospievajúceho a sociálne hendikepovaného chlapca môže empaticky a ústretovo stotožnit' (tematická a etická dimenzia postavy). Aj dve románové dievčenské postavy, napriek svojím charakterovým nedostatkom (nie sú ani dobré ani zlé) môžu u čitatel'a vyvolat' aktívny postoj k rozprávanému - s nimi sa adresát l'ahko identifikuje. S postavou Danky také stotožnenie je nežiaduce, hrdinka je príkladom tematického a funkčného kreovania postavy (s výchovnou tendenciou).

\section{Citovaná literatúra}

Bílek, Petr A.. Hledání jazyka interpretace. K modernímu prozaickému textu. Brno: Host, 2003.

Forster, Edward M. Aspekty románu. Bratislava: Tatran, 1971.

Fořt, Bohumil. Literární postava: vývoj a aspekty naratologických zkúmaní. Praha: Ústav pro českou literaturu AV ČR, 2008.

Harpáń, Michal. Teória literatúry. Bratislava: ESA, 1994.

Dziak, Dávid. „Ponúknime detskému čitatel’ovi prosociálne literárne vzory“. O diet’ati, jazyku, literatúre. VI, 2, 2018: 52-66.

Kubíček, Tomáš, Jiři Hrabal, Petr A. Bílek. Naratologie. Strukturální analýza vypřávění. Praha - Podlesí: Dauphin, 2013.

Rakús, Stanislav. „K niektorým genologickým, komunikačným a poetologickým otázkam epickej literatúry pre mládež“. [In:] Z. Stanislavová, V. Žemberová (eds.) Druhový a žánrový kontext v epike pre deti a mládež. Prešov: Náuka, 1999, 17-22.

Rusňak, Radoslav. (Ne)samozrejmé kapitoly z literatúry pre deti a mládež. Prešov: Prešovská univerzita v Prešove, Pedagogická fakulta, 2017.

Stanislavová, Zuzana. Priestorom spoločenskej prózy pre deti a mládež. Interpretačné štúdie. Prešov: Pedagogická fakulta UPJŠ, 1995.

Stanislavová, Zuzana. „Autenticita a detský aspekt (K poetike modernej a postmodernej 
detskej literatúry)“. [In:] V. Křivánek (ed.) Autenticita a literatura. Sborník referátů z literární konference 41. Bezručovy Opavy (16. - 17. 9. 1998). Praha - Opava: Ústav pro českou literaturu AV ČR, Filozoficko-přirodovědecká fakulta Slezké univerzity, Slezské zemské muzeum, 1999, 137-141. <http://www.ucl.cas.cz/edicee/images/data/ sborniky/1999/AAL/EP.pdf > 23.3.2021.

Stanzel, K. Franz. Teorie vyprávění. Praha: Odeon, 1988.

Zajac, Peter. Pulzovanie literatúry. (Tvorivost' literatúry II.). Bratislava: Slovenský spisovatel', 1993.

Zajac, Peter. „Autentickost’ ako rétorická figúra“. [In:] V. Křivánek (ed.) Autenticita a literatura. Sborník referátů z literární konference 41. Bezručovy Opavy (16. - 17. 9. 1998). Praha - Opava: Ústav pro českou literaturu AV ČR, Filozoficko-přirodovědecká fakulta Slezké univerzity, Slezské zemské muzeum, 1999, 21-28. <http://www.ucl. cas.cz/edicee/images/data/sborniky/1999/AAL/EP.pdf > 23.3.2021.

\section{Pramene}

Kotvášová-Jonášová, Mária. Mat' pätnást' je také t’ažké alebo Striptíz. Nový Sad: Hlas l'udu, 2007.

Kotvášová-Jonášová, Mária. Sú to vážne veci. Báčsky Petrovec: Slovenské vydavatel'ské centrum, 2010.

Kotvášová-Jonášová, Mária. Višňový lekvár. Báčsky Petrovec: Slovenské vydavatel'ské centrum, 2013.

\section{Zuzana Čižikova}

\section{KNJIŽEVNI LIK U PROZI MARIJE KOTVAŠOVE JONAŠOVE}

\section{Rezime}

Savremena slovačka spisateljica za decu i mlade, Marija Kotvašova Jonašova (1957), u svom stvaralaštvu se tematski fokusira na savremeni život dece i tinejdžera, žanrovski preferira pripovetku i roman sa nizom epizoda koje spaja protagonista, a poetski na tzv. dečji aspekat - pripovedanje i viđenje sveta iz dečje perspektive. U skladu s tim gradi i svoje dečje likove. Odabirom narativnih postupaka, načinom pripovedanja, načinom oblikovanja likova putem unutrašnjeg monologa i dramskog dijaloga (celokupnom stilizacijom teksta), autorka poštuje dečje viđenje sveta u skladu sa njegovom ontogenezom, ali i sa pretpostavljenim čitaocem, koji se u velikoj meri može identifikovati sa likom i prikazanim svetom. U romanu Mat' pätnást' je také t’ažké alebo Striptíz (Imati petnaest je tako teško ili Striptiz) lik tinejdžerke sadrži elemente tipizacije, ali dosledan uvid u njen psihički život doprinosi njenoj individualizaciji. Junakinja i pripovedač u knjizi Višňový lekvár (Pekmez od višanja) predstavlja karakterno određen lik luckaste devojčice, koji se u toku pripovedanja praktično ne menja, ali je njena karakterna osobina osnova svih prikazanih tenzija i konflikata. Oba ova ženska lika u velikoj meri evociraju „realno“ nestašno dete sa kojim se dete-čitalac može poistovetiti u značajnoj meri. Dečji lik sa hendikepom, Damjan, u istoimenoj prozi može takođe pozitivno uticati na primaoca, pre svega proizvođenjem poželjnih reakcija (empatija, solidarnost, humanost). U prozi „Danka“ junakinja se oblikuje samo indirektno - svojim delovanjem i govorom. Predstavlja lik kojim se ilustruje nepoželjni model ponašanja (lik ima tematsku i vaspitnu 
funkciju). Način oblikovanja književnih likova kod ove autorke preferira autentičnost realnosti; pre svega uz pomoć dečjeg aspekta (poštovanjem dečjeg načina razmišljanja i percipiranjem sebe i sveta oko sebe u skladu sa dečjim uzrastom), koji posmatramo kao stilsku figuru (stilizacija teksta) i kao ključni poetološki princip intencionalnog stvaralaštva za decu i mlade, gde se u obzir uzima dete-čitalac.

Ključne reči: Marija Kotvašova Jonašova, književni lik, dečji aspekat, autentičnost, stilizovanost, dete-čitalac. 